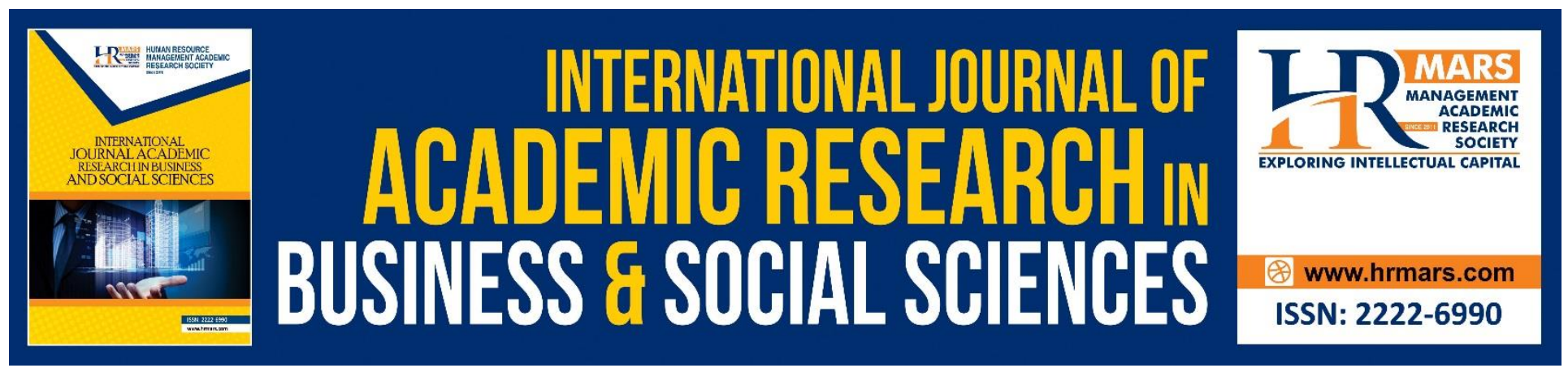

\title{
Perception of Service Quality among Malaysian University Recreational Fitness Center Users
}

Aminuddin Yusof, Arporn Popa and Soh Kim Geok

To Link this Article: http://dx.doi.org/10.6007/IJARBSS/v8-i7/4422

DOI: $10.6007 /$ IJARBSS/v8-i7/4422

Received: 21 May 2018, Revised: 23 June 2018, Accepted: 29 June 2018

Published Online: 17 July 2018

In-Text Citation: (Yusof, Popa, \& Geok, 2018)

To Cite this Article: Yusof, A., Popa, A., \& Geok, S. K. (2018). Perception of Service Quality among Malaysian University Recreational Fitness Center Users. International Journal of Academic Research in Business and Social Sciences, 8(7), 823-833.

Copyright: (C) 2018 The Author(s)

Published by Human Resource Management Academic Research Society (www.hrmars.com)

This article is published under the Creative Commons Attribution (CC BY 4.0) license. Anyone may reproduce, distribute, translate and create derivative works of this article (for both commercial and non-commercial purposes), subject to full attribution to the original publication and authors. The full terms of this license may be seen

at: http://creativecommons.org/licences/by/4.0/legalcode

\section{Vol. 8, No. 7, July 2018, Pg. 823 - 833}

Full Terms \& Conditions of access and use can be found at http://hrmars.com/index.php/pages/detail/publication-ethics 


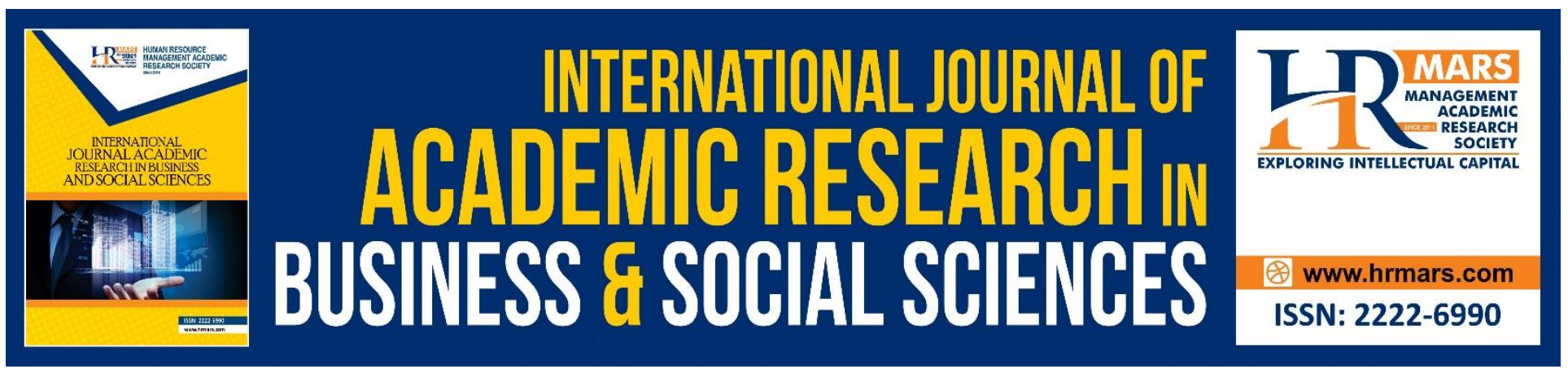

\title{
Perception of Service Quality among Malaysian University Recreational Fitness Center Users
}

\author{
Aminuddin Yusof ${ }^{1}$, Arporn Popa ${ }^{2}$ and Soh Kim Geok ${ }^{3}$ \\ 1,3 Faculty of Educational Studies, Universiti Putra Malaysia, 43400 UPM Serdang, Selangor, \\ Malaysia \\ ${ }^{2}$ Health \& Sport Science Department, Mahasarakham University, Thailand
}

\begin{abstract}
The purpose of this study was to examine user's perceptions of service quality and future intention to use campus recreation fitness center in Universiti Putra Malaysia. Data were collected from 200 students and staff of the university (males $=140$, females $=60$ ) who frequently used the campus recreation fitness center. The questionnaire consisted of items based on the Likert-scale Service Quality Assessment Scale (SQAS) developed by Lam, Zhang and Jensen (2005). Behavioral intention is based on three questions modified from Cunningham and Kwon (2003). The results showed that recreation fitness center users are satisfied with the overall staff service quality $(m=34.14)$ and fitness facility service quality $(m=34.14)$, but moderately satisfied with overall facility service quality $(m=30.77)$ and overall program service quality $(m=24.44)$. The findings indicated UPM recreation fitness center users have a high intention $(m=4.02)$ to recommend the recreation center to other people and to renew their membership. The result also shows overall staff service quality ( $B=.288 p$ $<.05)$ and overall facility service quality $(B=.251, p<.05)$ contribute significantly towards predicting behavioral intention. This means recreation fitness center users in UPM will continue their membership in the future or suggest other people to become members if they perceived the recreation fitness center as being conveniently located as well as user friendly in terms of safety and parking.
\end{abstract}

Keywords: Service Quality, Campus Fitness Center, Behavioural Intentions

\section{Introduction}

Health promotion at the workplace is often supported by public health professionals who often seek opportunities to reach a rarely captured audience (Goetzel and Ozminkowski, 2008). There is a great potential for on-site fitness programs for both health and work-related health effects. Evidence is suggesting increasing interest among employees in s activities to enhance their health and general wellbeing. University recreation fitness centers are similar to other workplace settings in terms of its ability offer a variety of fitness related activities and services for students and staff. Besides fitness and health classes, campus recreation fitness centers also provide opportunities for socialization, as well as sports and recreational activities. Recreation fitness center at university campuses may cost 
INTERNATIONAL JOURNAL OF ACADEMIC RESEARCH IN BUSINESS AND SOCIAL SCIENCES Vol. 8, No. 7, July 2018, E-ISSN: 2222-6990 @ 2018 HRMARS

millions but it creates an atmosphere of a livelier and meaningful campus life that benefits different stakeholders such as lecturers, staff and students. In turn a positive campus environment can enhance the competitiveness of a university and attract student enrollment (Shaver, 2005). Other benefits include relationship with the alumni for recruiting students as well as providing better job opportunities for future graduates.

The existence of a campus recreation fitness center is also important towards promoting healthy lifestyle on campus. This is will also help in stress reduction among students because a stress related problem on academic life as well as problems with college life (Belch, 2001), eating disorders (Thome \& Espelage, 2004), binge drinking (Kuther \& Timoshin, 2003), and adjusting with academic work. The campus recreation fitness center is an avenue for students to engage in recreational activities and the future adoption of a healthy lifestyle for the remaining of their adult life. Sallis (1986) suggests five characteristics of individuals engaging in healthy lifestyles: (1) a person with the self-confidence to succeed in exercise program; (2) knowledge of health and well-being; (3) knowledge of engaging in exercise; (4) understanding of the importance of regular exercise; and (5) their initial physical condition. Due to the large amount of money invested in building campus fitness facilities, it is important for university management to maximize usage of the recreation fitness center s. Therefore, understanding the service quality of these facilities is important because service quality has been shown to be related with continued usage of recreation fitness center s (Lagrosen and Lagrosen, 2007).

Service quality is a concept that provokes huge attention and argument in the research collected works because of the difficulties in both describing and evaluating it especially within the sports context because sport services are diverse and different dimensions will influence customers' perception of sport service (Goslin and Davies, 2014). But, research has shown that high service quality contributes significantly to profitability and indicates that it is very important for the marketer to improve and maintain service quality because customers can give a positive impact to the business performance when they gave a positive comment regarding service quality and this situation will lead to satisfaction and the loyalty of the customer to the company or product.

For fitness center managers and marketers, retention of members and measuring their loyalty are increasingly important (Smith, Murray and Howat, 2014). Research has shown that to retain customer and increase profits, it is important for the organization to provide excellent service (Avourdiadou and Theodorakis, 2014. In a fitness center, staff and customer often physically interacts. Services provided are complex and distinctive (Smith, Murray and Howat, 2014). Therefore, understanding needs and wants of the customer to provide the right service that matches these needs and wants. One unique feature of a fitness center is the involvement of the customer in producing the activity and consuming it at the same time. A major source of revenue is membership fees and directly related with fees is the ability of the fitness center to retain customers in the long run. Retention of members is important for profits and financial health of the center. Members' retention is related with loyalty which in turn is related to how they perceived the organisation's service quality. This leads to satisfaction if the customers satisfied with the service provided by the provider. So, it is important to measure and evaluate fitness centre service quality to meet the needs and wants of the customers. 
INTERNATIONAL JOURNAL OF ACADEMIC RESEARCH IN BUSINESS AND SOCIAL SCIENCES Vol. 8, No. 7, July 2018, E-ISSN: 2222-6990 @ 2018 HRMARS

\section{Purpose}

Measurement of service quality is important for a fitness facility to ensure the service quality level is consistently high and to identify the level of member satisfaction. It is widely accepted to determine service quality by post-experience customer research (Robinson, 2003). This allows sports organizations to identify weakness in service quality and introduce quality improvement. Most common type of measurement is done by using a survey given to users to find out whether users are satisfied with the service provided at the fitness facility. In the literature, there are many models to measure service quality. Among the most widely used is the Gap Model (Parasuraman et al. 1985). The Gap Model identify the difference between customers' expectations and their actual experience. The more the actual experience exceeds service expectations, the higher the perception of service quality. Even though the literature suggests service quality is related with consumer loyalty, it is not yet established in the fitness industry. Specific research focusing on campus recreational fitness facility is needed because campus fitness centers have several characteristics in terms of the programs it offers that differentiate them from commercial fitness centers which have been the focus of most research in this area.

In Malaysia, there has been limited number of studies done on fitness center but none focusing on university fitness (Boatenga, 2009; Yap, Othman and Kim, 2010). Currently most Malaysian studies focused on commercial fitness and health clubs (Yap et al, 2010) and not on campus fitness centers. Consequently, this study hopes to contribute to existing knowledge by studying the Malaysian campus fitness centers. It has been suggested that motivation is related with the satisfaction of fitness center users (Crossley, 2005; Ferrand, Robinson and Florence, 2010; Pellertier, Fortier, Vallerand, Tuson, Briere, and Blaise, 1995), but most studies do not explain the relationships between overall needs in terms of expectations and overall satisfaction.

It was reported by Boatenga, (2009) and Ramchadani and Coleman (2012) that motivation is the basis for customer membership, but previous studies lack the rigour of analysis as only T-test and ANOVA analyses were performed and have not used a more rigorous analysis such as the multiple regression analysis in examining the predictor variables. Most studies on service quality used the instrument based on Parasuraman et al, (1988) SERVQUAL model. However, the SERVQUAL has been noted for deficiencies in content, suffering from poor substantive and structural validity (Messick, 1995). The SERVQUAL has been criticized as being too general and lack detail information that can be used for the fitness industry especially on operational practice. The fitness industry is different from other industry in terms of the programs it offers, and this uniqueness is missing from the SERVQUAL (Brady \& Cronin, 2001; MacKay \& Crompton, 1988). As an alternative measuring instrument for the fitness industry Service Quality Assessment Scale (SQAS) was developed by Lam, Zhang \& Jensen (2005). The SQAS is a six-dimension (31 attributes) model and is an extension of previous service-quality models (e.g., Brady and Cronin, 2001; Parasuraman et al., 1988) and was developed to be more specific for sport and recreation settings (Papadimitriou and Karteroliotis, 2000).

Recently, more and more university campuses in Malaysia (Yusof, 2013) are establishing campus fitness facilities due to the concern that majority of university students are inactive and do not meet the minimum requirements for physical activity. For university administrators, building and maintaining fitness facilities on campus requires substantial investment in terms of money and man power. It is important for university administrators to determine whether staff and students use the 
INTERNATIONAL JOURNAL OF ACADEMIC RESEARCH IN BUSINESS AND SOCIAL SCIENCES Vol. 8, No. 7, July 2018, E-ISSN: 2222-6990 @ 2018 HRMARS

fitness facilities provided by the universities. Due to the substantial amount of investment in fitness facilities on campus and the financial commitment required for maintenance, university administration must ensure the usage of these facilities are at an optimal level. Thus, it is important for university management to measure the service quality of these facilities since satisfaction with service quality is one reason that always been cited (Lagrosen and Lagrosen, 2007) for continued usage of recreation fitness center s. Currently, no study has been done to examine the perception of service quality at campus recreation fitness center facilities as well as user intentions in terms of future usage in Malaysia. The importance of this research is to assist campus fitness center managers in Malaysia to receive information regarding fitness center user expectations of service quality as well as identifying problems to improve service quality of fitness center users.

Therefore, the purpose of this research is to examine user's perceptions of service quality and future intention to use campus recreation fitness center in Universiti Putra Malaysia (UPM).

The research questions for this study are:

1) What are the perceptions of overall staff service quality among recreation fitness center users in Universiti Putra Malaysia?

2) What are the perceptions of overall program service quality among recreation fitness center users in Universiti Putra Malaysia?

3) What are the perceptions of fitness facility service quality among recreation fitness center users in Universiti Putra Malaysia?

4) What are the perceptions of overall facility service quality among recreation fitness center users in Universiti Putra Malaysia?

5) What are the behavior intentions among recreation fitness center users in Universiti Putra Malaysia?

6 ) What are the relationship between perceptions of overall staff service quality, overall program service quality, fitness facility service quality and overall facility service quality and recreation fitness center users 'intention to use campus recreation fitness center in Universiti Putra Malaysia?

\section{Methodology}

Using convenient sampling technique, a total of 200 campus recreation fitness center users (males = 140 , females $=60$ ) comprising of students and staff from Universiti Putra Malaysia was selected to participate as subjects in the study. In terms of age, table 1 shows that most of the subjects from recreation fitness center $\mathrm{s}$ in both universities are in the 18-25 years old age group.

Table 1: Age of Subjects

\begin{tabular}{lcc}
\hline Age & $\mathbf{n}$ & $\%$ \\
\hline Under 18 & 0 & 0 \\
$18-25$ & 166 & 83.0 \\
$26-35$ & 18 & 9.0 \\
$36-50$ & 16 & 8.0 \\
More than 50 & 0 & 0
\end{tabular}


INTERNATIONAL JOURNAL OF ACADEMIC RESEARCH IN BUSINESS AND SOCIAL SCIENCES Vol. 8, No. 7, July 2018, E-ISSN: 2222-6990 @ 2018 HRMARS

The questionnaire consists of several parts. The first is question about demographic data such as age, gender, marital status, employment, membership status, frequency and duration of using the recreation fitness center facility. The data collection instrument was the $\mathbf{4 0}$ items Likert-scale Service Quality Assessment Scale (SQAS) developed by Lam, Zhang and Jensen (2005).The reliability for all constructs items was ranging from 0.71 to 0.85 for this instrument and the convergent validity of the measure was achieved which is each of the construct items ranging from .62 to .92 (Taghizadeh, Ghorbani and Begnam, 2015). This instrument is designed to evaluate service quality of health clubs and recreation fitness center $s$ by patrons and consists of six dimensions of service quality: staff, programme, locker room, physical facility, workout facility, and childcare. The theory of planned behavior (TPB) was used to measure behavioral intention to use campus recreation fitness center $\mathrm{s}$. For the study, behavioral intention is based on three questions modified from Cunningham and Kwon (2003).

\section{Results}

Table 2 shows the results of all the research questions. Regarding the first research question which is to examine the perceptions of recreation fitness center users about service quality, the results showed that recreation fitness center users are satisfied with the overall staff service quality $(m=34.14)$. Overall staff service quality refers to the possession of required knowledge and skills by staff of the recreation fitness center which according to Zeithaml, Parasuraman, \& Berry (1985), is important where customers prefer to work with trained or specialist staff or instructors according to predetermined and suitable programs to their needs. Thus, customer expects the staff to be knowledgeable and skillful. The staff of a health-fitness club represents the organization and promotes the service directly to the customer. Therefore, it is important for them be neat in terms of dressing and attire as well as show the willingness to assist users and the responsiveness to complaints. Provision of courtesy of service as well as courtesy ad patience are also part of the overall staff service quality and these factors focuses on how customers are treated in that fitness centre such as individual attention and caring from the in the fitness centre (Nietos, Zournatzi, Koustelios and Costa, 2015).

Table 2: Results based on Research Questions

\begin{tabular}{llll}
\hline & N & Mean & Sd \\
\hline & & & \\
RQ1 : Perceptions of Overall Staff Service Quality & 200 & 34.14 & 4.11 \\
RQ2: Perceptions of Overall Program Service Quality & 200 & 24.44 & 4.41 \\
RQ3: Perceptions of Fitness Facility Service Quality & 200 & 18.86 & 2.39 \\
RQ4: Perceptions of Overall Facility Service Quality & 200 & 30.77 & 3.78 \\
\hline
\end{tabular}

The second research question seeks to examine the perceptions of overall program service quality among campus recreation fitness center users. The results are shown in Table 2. According to Lam, Zhang \& Jensen (2005), customer satisfaction is affected most by the program element, but this factor was not included in other service-quality models that were generally designed for other sectors but not for recreation fitness center $\mathrm{s}$. The overall program service quality dimension as proposed by Kim and Kim (1995) refers to whether different types of programs and activities are organised such as 
INTERNATIONAL JOURNAL OF ACADEMIC RESEARCH IN BUSINESS AND SOCIAL SCIENCES Vol. 8, No. 7, July 2018, E-ISSN: 2222-6990 @ 2018 HRMARS

sport programs, family activities and community. Overall program service quality also includes attributes such as adequacy of space, convenience of time and schedule, appropriateness of class size, availability of appropriate activities as well as quality content of programs. Besides having a spacious gym floor to conduct activities, recreation fitness center users in UPM perceived the campus recreation fitness center to have a variety of different activities offered besides the normal free weights activities conducted at other recreation fitness center $\mathrm{s}$ such as personal training class and exercise class activities involving Zumba exercise.

The third research question examines the perceptions of UPM recreation fitness center users about their perceptions of fitness facility service quality. This refers to the availability of modern-looking equipment, adequacy of signs and directions, variety of fitness and exercise equipment. It also refers to the availability of workout facility and equipment as well as the overall maintenance of facility and equipment. The results suggest UPM university recreation fitness center users are satisfied $(m=34.14)$ with the fitness facility service quality in terms of the facility having equipment which are new and modern looking as well as having a variety of different fitness equipment. Besides general strength training equipment such as dumbbells and barbells, UPM recreation fitness center also has other equipment such as variable resistance training equipment, lifting accessories, bodyweight training, and calisthenics as well as gymnastics equipment.

The fourth research question examines the perceptions of overall facility service quality between recreation fitness center users in UPM. The results show UPM recreation fitness center users have a moderate level of satisfaction $(m=30.77)$ with overall facility service quality suggesting areas of improvement in terms of convenience of location, hours of operation, availability of parking as well as parking lot safety. It also refers to the need to have better temperature control, lighting and pleasantness of the facility in terms of environmental friendly. The next research question examines the behaviour intentions of recreation fitness center users. Behaviour intention is defined as the concept of trying to perform a behavioral goal or a given behavior (Ajzen, 1991). In this study two questions were used to measure behavior intentions. The first asked respondents whether will recommend the recreation center to other people while the second asked respondents whether they have the intention to renew their membership. The results as shown in Table 3 suggest UPM recreation fitness center users have high intentions $(\mathrm{m}=4.02)$ to recommend the recreation center to other people and to renew their membership.

Table 3: Behaviour Intentions

N Mean SD

$200 \quad 4.02 \quad .04$

Table 4 shows the relationship between perceptions of overall staff service quality, overall program service quality, fitness facility service quality and overall facility service quality and recreation fitness center users 'intention to use campus recreation fitness center s in UPM. Overall, behavior intention of UPM recreation fitness center users could be best predicted by overall staff service quality and 
INTERNATIONAL JOURNAL OF ACADEMIC RESEARCH IN BUSINESS AND SOCIAL SCIENCES Vol. 8, No. 7, July 2018, E-ISSN: 2222-6990 @ 2018 HRMARS

overall facility service quality, $\mathrm{R}^{2}=.248, \mathrm{R}^{2}$ adj $=.237, \mathrm{~F}(4,196)=21.597, \mathrm{p}<.05$. Based on this analysis, it is shows overall staff service quality $(B=.288 p<.05)$ and overall facility service quality ( $\beta$ $=.251, \mathrm{p}<.05)$ contribute significantly towards predicting behavioral intention. The results mean recreation fitness center users in UPM will continue their membership in the future or suggest other people to become members if they perceived the recreation fitness center as being conveniently located as well as user friendly in terms of safety and parking. In addition, the future behavior intention of recreation fitness center users in UPM is also influenced by the willingness of staff of the recreation fitness center to assist users and the responsiveness to complaints.

Table 4: Multiple Regression of Predictors of Intentions for UPM Recreation Fitness Center Users

\begin{tabular}{llll}
\hline \multicolumn{1}{c}{ Variable } & $\beta$ & $t$ & $p$ \\
\hline & & & \\
Overall staff service quality & .288 & 3.713 & $.001^{*}$ \\
Fitness facility service quality & .033 & 0.405 & .686 \\
Overall facility service quality & .251 & 2.950 & $.040^{*}$ \\
Overall program service quality & .026 & 0.525 & .415 \\
\hline
\end{tabular}

$* p<.05$

\section{Discussion}

This study assumes that service quality and would result in satisfaction and influence behavior intention to frequent the university recreation fitness center. This assumption is based on the Customer Satisfaction Theory (Klaus, 1985) which views service quality from customer's perspective, where if the fitness center user feels satisfied with the provided service, then the service at the campus fitness center can be considered as possessing quality. This assumption was supported by the results of the study which showed behavior intention of UPM fitness center users could be best predicted by overall staff service quality and overall facility service quality. It was found out that, good quality service would influence users to recommend the fitness center to other people and influence them to renew their membership. Further, the quality of service provided directly results in satisfaction which in turns influence behavior intention of fitness center users.

Based on this finding, it is recommended for fitness center at the university to regularly evaluate the quality of service provided to users, establish and maintain high quality standards and following Zeithaml and Bitner (1996), the university fitness center should be concerned in providing service quality in terms of the tangible and intangible aspects of service quality. The tangible aspect of service quality covers factors related to the fitness facility service quality such as new equipment, layout and design of fitness center, the supply of towels, lockers and other accessories and maintenance of facility and equipment. Besides having traditional equipment such as dumbbells and barbells, users also perceived quality service in terms of availability of tangible equipment such as variable resistance training equipment, lifting accessories, bodyweight training, calisthenics as well as gymnastics equipment. A fitness centre shares some similarity with a spa or a health centre in terms of the layout and the ambience. These two elements create a sense of environment which are comfortable and suitable for users to work out. Maintenance of equipment is important to ensure all equipment are properly functioning to create a conducive atmosphere for working out and to relax. 
INTERNATIONAL JOURNAL OF ACADEMIC RESEARCH IN BUSINESS AND SOCIAL SCIENCES Vol. 8, No. 7, July 2018, E-ISSN: 2222-6990 @ 2018 HRMARS

The other aspect of service quality is the intangible aspect. Services provided at a fitness center are intangible and should be viewed as performances instead of physical objects. Unlike physical objects, services cannot be tested and standardized and there are few cues that a customer can rely on to judge the quality of a service (Parasuraman et al 1985; Zeithaml, Berry and Bitner, 1996). In this study, intangible aspect of service facility refers to customers' perception of overall staff service quality such as knowledgeable and skillful staff and positive interaction between staff and users. Sincerity when engaging with users as well as being polite during interactions are important elements towards customer satisfaction. This would require hiring staff with the right attitude and knowledge as well as providing training and development of quality staff. Intangible aspect also refers to overall service facility such as the convenience of location, hours of operation, availability of parking as well as parking lot safety. It also refers to temperature control, lighting and pleasantness of the facility in terms of environmental friendly. Management of fitness centers should focus on friendly and comfortable atmosphere, convenient location and scheduling, and positive attitude of the staff. Management could also obtain other information regarding what tangible and intangible aspects the center should focus on by getting feedback from users either by using feedback forms or verbally.

\section{Conclusion and Suggestions}

The main conclusion drawn from this study is that campus fitness center user positive perceptions and satisfaction on service quality can influence their future intentions of using the fitness facility. University administrators could use the findings to attract more students and staff to frequent and use the fitness centers by constantly evaluating the tangible and intangible aspects of service quality. It is important that that user satisfaction be constantly monitored as this is key to loyalty and retention. To get more staff and students to use the campus fitness center, a change in the system of managing the campus fitness center is needed. The way forward is through commercialization of the fitness center and formulating a strategy to make people pay for using the fitness center. There is a need to shift from focusing on delivering services to the managing of experience of all fitness center users so that they are willing to pay for the time they spent at the fitness center. This will involve applying the concept of the experience economy, first proposed by Pine and Gilmore (1998). Since the concept of the experience economy has taken root, businesses have given more attention on experiential marketing that apply the experience staging in the marketing of goods and services, replacing the traditional media as a means of creating demand. The digital media and internet are the new platform for creating experiences and building the demand for goods and services. Additionally, the concept of experience economy has been embraced in many different fields such as retailing (Grewal, Levy, and Kumar 2009), branding (Atwal and Williams 2009; Brakus, Schmitt, and Zarantonello 2009), entertainment and arts (Petkus 2004), architecture and urban planning (Howell 2005; Lorentzen 2009). In sports, the concept has been applied to extreme sports which are associated with Csikszentmihalyi (1995) flow experiences.

The ability to attract staff and students to use the fitness center would encourage staff and students to lead a much healthier lifestyle and at the same time allow them more freedom to enjoy better work life balance. The current trend of more youngsters seeing the importance of exercise through school programme is something positive but most of these adolescents would stop a healthy lifestyle once they finish school (Ong and Andrews, 2011). Thus, it is the role of universities to entice university students to continue their healthy living through having a well-managed fitness center. The campus 
INTERNATIONAL JOURNAL OF ACADEMIC RESEARCH IN BUSINESS AND SOCIAL SCIENCES

Vol. 8, No. 7, July 2018, E-ISSN: 2222-6990 @ 2018 HRMARS

fitness center is an avenue for students to engage in recreational activities and the future adoption of a healthy lifestyle for the remaining of their adult life. The following are some suggestions on ways to attract more students and staff to use the university recreation fitness center:

1. Create a better schedule that can increase attendance as well as attracting new users

2. Perform live demonstrations of activities in open public spaces in both universities to attract attention and increase awareness of the fitness centers' offerings.

3. Encourage current users to bring friends and family to the fitness centers on special occasions for free. This will provide opportunity to engage with potential members outside the university.

4. Provide a specialized beginners programme to help create a good first-time impression for the prospective members or a new member who have just signed up. The programme should be designed to assimilate the new member into the environment of the club at his/her pace with the goal of enhancing their engagement experience each time.

5. Provide privileges and special benefits for loyal members who have maintained their membership for a certain period. This will encourage members to continue and retain their membership.

6. Take proactive actions not only to maintain, but to upgrade the quality of the equipment when necessary in the fitness center.

\section{References}

Ajzen, I. (1991). The theory of planned behavior. Organizational behavior and human decision processes, 50, 179-211.

Atwal, G., \& Williams, G. (2009). Luxury brand marketing: The experience is everything! Journal of Brand Management 16, (5-6): 338-346.

Avourdiadou, S. \& Theodorakis, N. (2014). The development of loyalty among novice and experienced customers of sport and fitness centers. Sport Management Review, 17(4), 419-431.

Belch, H. A., Gebel, M., and Mass, G. M. (2001). Relationship between Student Recreation Complex Use, Academic Performance and Persistence of First-Time Freshman, NASPA Journal, 38, pp. 254-268.

Brakus, J., Schmitt, B. and Zarantonello, L. (2009). Brand Experience: What Is It? How Is It Measured? Does It Affect Loyalty? Journal of Marketing, 73, pp.52-68.

Csikszentmihalyi, M. (1975). Beyond Boredom and Anxiety: The Experience of Play in Work and Games. San Francisco: Jossey-Bass Publishers.

Cunningham, G.B. and Kwon, H. (2003) The Theory of Planned Behaviour and Intentions to Attend a Sport Event. Sport Management Review, 6, 127-145.

Goetzel, R.Z., Ozminkowski, R.J., Bowen, J., \& tabrizi, M.J. (2008) Employer integration of health promotion and health protection programs. International Journal of Workplace Health Management, Vol. 1 Issue: 2, pp.109-122.

Goslin, A. E. \& Davies, K. (2014). Measuring service quality of international tennis coach education courses. African Journal for Physical, Health Education, Recreation and Dance, 20(1), 11-23.

Grewal, D., Levy, M., \& Kumar., V. (2009). Customer experience management in Retailing: An organizing framework. Journal of Retailing, 85 (1): 1-14.

Howell, J. (2005). Manufacturing experiences: Urban development, sport and recreation. International Journal of Sport Management and Marketing, 1 (1-2): 56-68. 
INTERNATIONAL JOURNAL OF ACADEMIC RESEARCH IN BUSINESS AND SOCIAL SCIENCES

Vol. 8, No. 7, July 2018, E-ISSN: 2222-6990 @ 2018 HRMARS

Kim, D., \& Kim, S. Y. (1995). QUESC: An instrument for assessing the service quality in sport and leisure center customers. Journal of Sport Management, 9, 208-220.

Klaus, P. (1985). Quality epiphenomenon: the conceptual understanding of quality in face-to face service encounters", in Czepiel, J.A., Solomon, M.R., Suprenant, C.F. and Gutman, E.G. (Eds), The Service Encounter: Managing Employee Customer Interaction in Service Business, Lexington Books, Lexington, MA.

Kuther, T.L., \& Timoshin, A. (2003). A comparison of social cognitive and psychosocial predictors of alcohol use by college students. Journal of College Student Development, 44(2), 143-154.

Lam, E., Zhang, J., \& Jensen, J. (2005). Service quality assessment scale (SQAS): as instrument for evaluating service quality of health fitness clubs. Measurement in Physical Education and Exercise Science, 9:79-111.

Lagrosen, S. \& Lagrosen, Y. (2007). Exploring service quality in the health and fitness industry. Journal of Service Theory and Practice, 17(1), 41-53.

Nietos, I. F., Zournatzi, E., Koustelios, A. \& Costa, G. (2015). Relationship among service quality, customer satisfaction, and renewal intentions in recreation theme park in Greece. International Journal of Sport Management Recreation and Tourism, (18):41-55.

Ong, L. T., Andrews, E. and Tan, S.L. (2012). A Study of Customer Retention and Churn Management through Data Mining and Customer Profiling of Malaysian Mobile Users. Proceedings of the Academy of World Business Marketing and Management Development (AWBMAMD) Conference, Budapest, Hungary, 5(1), July 2011, pp. 197-210.

Parasuraman, A., Zeithaml, V. A. \& Berry, L. L. (1985). A conceptual model of service quality and its implications for future research. American Marketing Association, 49(4):41-50.

Petkus, E. (2004). Enhancing the Application of Experiential Marketing in the Arts. International Journal of Nonprofit and Voluntary Sector Marketing, 9 (1): 49-56.

Pine, J. and Gilmore, J. (1998). Welcome to the Experience Economy. Harvard Business Review, pp.97105.

Sallis, J.F., Haskell. W.L., Fortmann, S.P., Vranizan, K.M., Taylor, C.B., \& Solomon, D. (1986). Predictors of adoption and maintenance of physical activity in a community sample. Preventive Medicine, 15 (4), 331- 341

Smith, J., Murray, D., \& Howat, G. (2014). How perceptions of physique can influence customer satisfaction in health and fitness centers. Managing Leisure, 19(6):442-460.

Thome, J. and Espelage, D.L. (2004) Relations among Exercise, Coping, Disordered Eating, and Psychological Health among College Students. Eating Behaviors, 5, 337-351.

Yusof, A., Chuan, C.C. \& Shah, P. (2013). Academic achievement and sports involvement of Malaysian university athletes. Procedia - Social \& Behavioral Sciences, 106, 273-281.

Zeithaml, V., Berry, L. and Parasuraman, A. (1996). The Behavioral Consequences of Service Quality, Journal of Marketing, 60, pp. 31-46.

Zeithaml, V. and Bitner, M. (2000). Services Marketing: Integrating Clients' Focus across Firms. New York: McGraw-Hill. 